\section{'Sable' Strawberry}

\author{
A.R. Jamieson ${ }^{1}$, N.L. Nickerson ${ }^{2}$, C.F. Forney ${ }^{3}$, and K.A. Sanford ${ }^{4}$ \\ Agriculture and Agri-Food Canada, Atlantic Food and Horticulture Research \\ Centre, 32 Main Street, Kentville, NS, B4N 1J5, Canada
}

\section{K.R. Sanderson ${ }^{5}$}

Agriculture and Agri-Food Canada, Crops and Livestock Research Centre, 440 University Avenue, Charlottetown, PE, C1A 4N6, Canada

\section{J.-P. Privé}

Agriculture and Agri-Food Canada, Senator HervéJ. MichaudResearch Farm, 1045 St. Joseph Road, P.O. 2069, Bouctouche, NB, E4S 2J2, Canada

\section{R.J.A. Tremblay ${ }^{7}$ \\ N.B. Department of Agriculture, Fisheries, and Aquaculture, 850 Lincoln Road, Fredericton, NB, E3B 9H6, Canada}

Additional index words. Fragaria $\times$ ananassa, Phytophthora fragariae, red stele root rot resistance, fruit breeding
'Sable' strawberry (Fragaria xananassa Duchesne) was commercially introduced in Canada in June 1998 by the Atlantic Food and Horticulture Research Centre of Agriculture and Agri-Food Canada. 'Sable' ripens in early season, offering growers an alternative to $F$. xananassa 'Veestar' and $F$. xananassa 'Annapolis', with greater productivity and broader disease resistance. Plants of 'Sable' are vigorous and resistant to red stele root rot disease (incited by Phytophthora fragariae Hickman var. fragariae) and several leaf diseases. Fruit are well formed, attractive, and flavorful. The name 'Sable' is significant in Nova Scotia, representing several geographical features including a river and an island.

\section{Origin}

'Sable', tested as K90-1, is a seedling from a 'Veestar' $x F$. xananassa 'Cavendish' cross made under the direction of A.R. Jamieson in 1988 at Kentville, N.S. 'Veestar' became a very successful early season cultivar in eastern Canada soon after its introduction by C.L. Rick-

Received for publication 1 May 2002. Accepted for publication 22 Aug. 2002. Atlantic Food and Horticulture Research Centre Contribution no. 2242. We thank K.B. McRae, S. Fillmore, and B. Walker for assistance with experimental design and analysis. We thank the following cooperators who evaluated 'Sable' for suitability to their area: P. Hendrickson (Newfoundland), C.G. Davidson (Manitoba), L. Hausher (Alberta), D.T. Handley (Maine), and D.K. Wildung (Minnesota). For technical support, we thank A.C. Brydon, M. Graves, P. Rand, R.J. Davies, C. Burbidge-Boyd, J. Richards, and K. Nicolas. For helpful comments on the manuscript, we thank E. Jackson and J. Delong.

${ }^{1}$ Fruit Breeder; to whom reprint requests should be addressed. E-mail address: jamiesona@em.agr.ca

${ }^{2}$ Mycologist.

${ }^{3}$ Postharvest Physiologist.

${ }^{4}$ Sensory Scientist.

${ }^{5}$ Horticulturist.

${ }^{6}$ Fruit Crop Physiologist.

${ }^{7}$ Small Fruit Specialist. etson of the Horticultural Research Institute of Ontario, Vineland Station, in 1967. 'Cavendish' is a large-fruited early-midseason cultivar that has resistance to red stele root rot (Jamieson et al., 1991). The cross was intended to combine the early fruiting habit of 'Veestar' with the fruit size and red stele root rot resistance of ' $\mathrm{Cav}$ endish'. Seedlings of the cross were screened for red stele resistance using the sand bench method of Scott et al. (1976) with six isolates of race A-6 as inoculum. Symptomless plants were moved to a poorly drained field infested with $P$. fragariae located at Sheffield Mills, Kings Co., N.S., in Spring 1989. 'Sable' was selected in 1990 by A.R.Jamieson as the first selection of the strawberry season, based on its early ripening and good flavor.

\section{Description and Performance}

'Sable' has been tested widely in Atlantic Canada in regional trials planted in 1994, 1997, and 1999, in Nova Scotia, New Brunswick, Prince Edward Island, and Newfoundland.
Trials located in Atlantic Canada consisted of matted rows developed from seven plants set at $50 \mathrm{~cm}$. A 3-m section of each row, centered on the midpoint, was harvested in each trial two times per week. Each site had three replicates and plots were harvested for two successive years. 'Sable' has also been tested in Minnesota, Manitoba, and Alberta. These trials were also laid out as replicated matted rows but varied as to the number of replications and the length of the rows. The Minnesota trials consisted of mulched and unmulched plots to better evaluate winter hardiness. In the Atlantic Canada regional trials, the data collected included marketable and unmarketable yield, and fruit weight based on a 25 -fruit sample from each row on each harvest date. Mean fruit weight and mean harvest date were calculated on each row, and values were weighted by yield as described by Moore (1970) to give seasonal means. Fruit firmness was determined after storage by penetration using an Ametek firmness tester (Ametek, Hunter Spring Division, Hatfield, Pa.) with a 6-mm o.d. v-notched tip. The maximum force that occurred during insertion of the probe $6 \mathrm{~mm}$ into each of 10 fruit was recorded and the 10 values were averaged. An additional 10-fruit-sample was used to measure bruising, color, and shine. Bruising was rated subjectively on a scale of 1 (not bruised) to 5 (highly bruised). Color and shine were rated by comparing fruit to Munsell Color Chips (MacBeth, Baltimore, Md.). All statistical analyses were performed with Genstat 5.31 (Payne et al., 1993).

Plants of 'Sable' are vigorous and consistently runner well to fill matted-row beds. Crown size is small to medium, smaller than for $F$. xananassa 'Kent', and often branching. Leaves are trifoliate: the central leaflet is longer than wide (1.2 length : 1.0 width), with an acute base and obtuse serrations. Leaflets tend to be cupped. Leaf petioles are medium long with a medium density of outwardly oriented hairs. Flower clusters are produced on medium long peduncles, longer than 'Veestar', and flowers open at the height of the canopy. Petals are wider than they are long $(0.8$ length : 1.0 width)

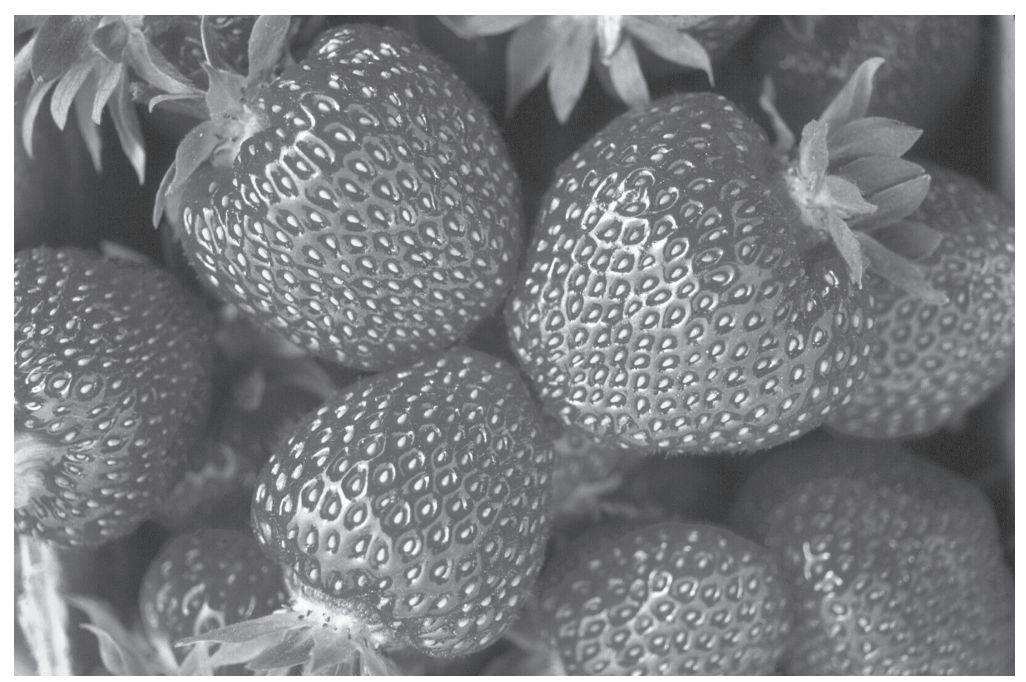

Fig. 1. 'Sable' strawberries. 
Fruit are medium in size and typically cordate to short conic in shape, without a neck (Fig. 1). The larger primary fruit have a broad tip, giving a wedge shape. The calyx is typically appressed to the fruit and its diameter is smaller than the diameter of the fruit. The calyx is easily removed from the fruit, similar to 'Veestar'. Fruit surface is a glossy, bright red with a lighter interior color.

'Sable' is less suitable than 'Kent' for shipping as determined by postharvest evaluations (Table 1). Compared to 'Kent', 'Sable' is less firm and more prone to bruising. Red-ripe 'Sable' tended to lack glossiness after $7 \mathrm{~d}$ of storage. 'Sable' tends to accumulate sugars early in the ripening process, which contributes to high fresh-picked flavor. The consumer acceptance of 'Annapolis', 'Sable', and 'Veestar' was measured by a panel composed of 50 to 60 staff members. Samples were drawn from two harvests in 1993 and 1994 for 'Annapolis', one harvest in 1993 and 1994 for 'Sable', and one harvest in 1993 for 'Veestar'. Panelist scores for the flavor, texture, and overall acceptance of the three cultivars were similar (Table 2).

'Sable' ripens in the early season. The seasonal average harvest date, when weighted according to the yield at each harvest, is usually not different from the harvest date for 'Veestar' or 'Annapolis' (Table 3). Compared with 'Annapolis', the leading early season cultivar in eastern Canada, the duration of harvest is 2 $\mathrm{d}$ longer. The harvest period was $17.6 \mathrm{~d}$ for 'Annapolis' and 19.7 d for 'Sable' in 2000, averaged over three sites.

'Sable' has proven to be more productive than other early season cultivars (Table 3 ). The highest marketable yield for 'Sable', $19.8 \mathrm{t} \cdot \mathrm{ha}^{-1}$, was produced in the maiden crop year at Charlottetown in the trial planted in 1994. In the Atlantic provinces, yields of 'Sable' are generally greater than 'Veestar' and 'Annapolis'. 'Sable' fruit weight, when averaged over the harvest season, is greater than 'Veestar'but less than 'Annapolis' (Table 3). The higher yields but smaller fruit of 'Sable' when compared to 'Annapolis' has been confirmed in trials in Manitoba, Minnesota, Iowa, Wisconsin, and Michigan(C.G. Davidson, D.K. Wildung, G.R. Nonnecke, B.R. Smith, and E.J. Hanson, respectively, pers. comm.). In Maine in 2000, 'Sable' was more productive than the other early season cultivars tested, 'Evangeline' and 'Mohawk' (Handley and Dill, 2002). 'Sable' has demonstrated a high level of winter-hardiness and spring vigor. In unmulched plots in Grand Rapids, Minn., 'Sable' had the highest spring plant stand ratings in a trial of 24 entries in 1998 (D.K. Wildung, pers. comm.). In Morden, Man., the winter injury ratings and vigor ratings of 'Sable', rated in Spring 1997, were better than ratings for 'Veestar' and 'Honeoye' (C.G. Davidson, pers. comm.).

\section{Disease Response}

'Sable' is highly resistant to $P$. fragariae var. fragariae Canadian races 2, 3, 4 and is moderately resistant to race 1 as measured in a controlled environment test with potted plants (Nickerson and Murray, 1993). This pat-

Table 1. Fruit characteristics of 'Sable' and 'Kent' harvested underripe ( $75 \%$ to $95 \%$ red) or red-ripe (100\% red) following storage for $5 \mathrm{~d}$ at $1{ }^{\circ} \mathrm{C}$ and $2 \mathrm{~d}$ at $15^{\circ} \mathrm{C}$.

\begin{tabular}{lccccccc}
\hline Cultivar $^{\mathrm{y}}$ & $\begin{array}{c}\text { Fruit maturity } \\
\text { at harvest }\end{array}$ & $\begin{array}{c}\text { Firmness }^{\mathrm{z}} \\
(\mathrm{N})\end{array}$ & $\begin{array}{c}\text { Bruise } \\
\text { rating }^{\mathrm{x}}\end{array}$ & $\begin{array}{c}\text { Color } \\
\text { rating }^{\mathrm{w}}\end{array}$ & $\begin{array}{c}\text { Shine } \\
\text { rating }^{\mathrm{v}}\end{array}$ & TSS $(\%)$ & TA (\%) \\
\hline Kent & Under ripe & 5.15 & 2.2 & 3.0 & 4.5 & 6.0 & 0.80 \\
& Red ripe & 3.95 & 3.1 & 5.6 & 4.4 & 7.2 & 0.72 \\
Sable & Under ripe & 4.02 & 3.3 & 2.0 & 4.7 & 7.2 & 0.97 \\
& Red ripe & 3.41 & 3.6 & 3.2 & 3.0 & 7.0 & 0.90 \\
SEM $(\mathrm{n}=8)$ & & 0.626 & 0.38 & 0.46 & 0.45 & 0.52 & 0.089 \\
Degrees of freedom & 68 & 70 & 70 & 68 & 69 & 69 \\
\hline
\end{tabular}

${ }^{2}$ Fruit firmness was determined by penetration using an Ametek firmness tester with a 6-mm o.d. v- notched tip. The maximum force that occurred during insertion of the probe $6 \mathrm{~mm}$ into each of 10 fruit was recorded and the 10 values were averaged.

${ }^{y}$ Values of 'Kent' are from two harvest dates from each of three commercial fields; values of 'Sable' are from evaluations done on two harvest dates from one commercial field. The data presented is part of a larger study involving seven genotypes and the means are based on eight samples (quarts).

${ }^{x}$ Ratings on a scale of 1 to 5 , where $1=$ not bruised and $5=$ highly bruised.

"Ratings on a scale of 1 to 7, where $1=$ light red and $7=$ deep red using Munsell Color Chips (MacBeth, Baltimore, Md.).

${ }^{v}$ Ratings on a scale of 1 to 7 , where $1=$ flat and $7=$ high gloss using Munsell Color Chips.

Table 2. Consumer panel evaluation of fruit flavor, texture, and overall acceptability of 'Annapolis', 'Sable', and 'Veestar' grown at Kentville, N.S., in 1993 and 1994.

\begin{tabular}{lccc}
\hline Cultivar & Flavor $^{\mathrm{z}}$ & Texture $^{\mathrm{z}}$ & Overall $_{\text {acceptance }}^{\mathrm{z}}$ \\
\hline Annapolis & 4.6 & 5.3 & 5.0 \\
Sable & 4.7 & 4.9 & 4.9 \\
Veestar & 4.2 & 4.7 & 4.4 \\
SED $^{\mathrm{y}}$ (average) & 0.36 & 0.32 & 0.36 \\
\hline
\end{tabular}

${ }^{7}$ Mean values of scores on a 9 point hedonic score $(1=$ dislike extremely; $9=$ like extremely) as rated within $4 \mathrm{~h}$ of harvest, as part of a larger study involving 22 genotypes.

${ }^{y}$ Standard error of the difference. Components of variation and cultivar means estimated by the Restricted Maximum Likelihood Technique (Payne et al., 1993).

Table 3. Fruit production ${ }^{z}$ of 'Sable' and standard early season cultivars for 1995 to 2000 averaged over sites in Atlantic Canada.

\begin{tabular}{|c|c|c|c|c|}
\hline \multirow[b]{2}{*}{ Cultivar } & \multicolumn{2}{|c|}{ Yield $\left(\mathrm{t} \cdot \mathrm{ha}^{-1}\right)$} & \multirow{2}{*}{$\begin{array}{c}\text { Wt/fruit } \\
(\mathrm{g})\end{array}$} & \multirow{2}{*}{$\begin{array}{l}\text { Mean harvest } \\
\text { (day of year) }\end{array}$} \\
\hline & Marketable & Unmarketable & & \\
\hline \multirow{4}{*}{$\begin{array}{l}\text { Sable } \\
\text { Veestar }\end{array}$} & & 1995 (four sites) & & \\
\hline & $15.7 a^{y}$ & $1.7 \mathrm{a}$ & $12.7 \mathrm{a}$ & $191.7 \mathrm{a}$ \\
\hline & $11.6 \mathrm{~b}$ & $1.2 \mathrm{~b}$ & $8.7 \mathrm{~b}$ & $191.5 \mathrm{a}$ \\
\hline & & 1996 (four sites) & & \\
\hline Sable & $11.7 \mathrm{a}$ & $1.8 \mathrm{a}$ & $9.0 \mathrm{a}$ & $192.8 \mathrm{a}$ \\
\hline \multirow[t]{2}{*}{ Veestar } & $11.5 \mathrm{a}$ & $1.3 \mathrm{~b}$ & $7.0 \mathrm{~b}$ & $193.3 \mathrm{a}$ \\
\hline & & 1998 (one site) & & \\
\hline Sable & $17.2 \mathrm{a}$ & $2.5 \mathrm{a}$ & $11.7 \mathrm{a}$ & $180.3 \mathrm{a}$ \\
\hline \multirow[t]{2}{*}{ Veestar } & $11.1 \mathrm{~b}$ & $0.9 \mathrm{~b}$ & $8.0 \mathrm{~b}$ & $178.3 \mathrm{~b}$ \\
\hline & & 2000 (three sites) & & \\
\hline Sable & $10.2 \mathrm{a}$ & $1.5 \mathrm{a}$ & $9.6 \mathrm{~b}$ & $191.7 \mathrm{a}$ \\
\hline Annapolis & $6.8 \mathrm{~b}$ & $0.5 \mathrm{~b}$ & $11.9 \mathrm{a}$ & $192.8 \mathrm{a}$ \\
\hline
\end{tabular}

${ }^{2}$ Data for 1995 and 1996 from plots established in 1994; data for 1998 from plots established in 1997; data for 2000 for plots established in 1999. Data from entire trials, containing 14 to 16 cultivars or selections, were used in the analysis of variance. ${ }^{y}$ Mean separation within columns and years by LSD test at $P \leq 0.05$.

tern of resistance is effective in most fields in Canada because these are the most common races (Nickerson and Jamieson, 1995). The reaction to race 1 distinguishes 'Sable' from 'Annapolis' and 'Cavendish', which are susceptible.

In field plots at Kentville, 'Sable' plants have demonstrated resistance to leaf scorch [caused by Diplocarpon earliana (Ellis \& Everh.) F.A. Wolf] and leaf spot [caused by Mycosphaerella fragariae (Tul.) Lindau]. Powdery mildew [caused by Sphaerotheca macularis (Wallr.:Fr.) Jacz. f. sp. fragariae] has been observed and 'Sable' appears to be as susceptible as 'Annapolis'. Fruit rot (caused by Botrytis cinerea Pers.:Fr.) has been more severe on 'Sable' than 'Veestar' and 'Annapolis' and this is reflected in its larger unmarketable portion of harvested fruit (Table 3 ). Virus diseases of strawberries are uncommon in Atlantic Canada, and the virus tolerance of 'Sable' is unknown. Green petal disease (caused by clover phyllody phytoplasma) is common, however, but 'Sable' has not been significantly affected in plots where 'Cavendish' has had a high incidence. 
'Sable' appears to be well adapted throughout the Atlantic provinces of Canada. In preliminary trials in north-continental climates, 'Sable' has demonstrated good winter-hardiness and spring vigor. 'Sable' will be of particular value on soils infested with $P$. fragariae var. fragariae, providing a high-yielding early season cultivar for local markets.

\section{Availability}

Certified 'Sable' plants are being propagated under royalty agreements with licensed nurseries, the names of whom will be supplied upon request. The Atlantic Food and Horticulture Research Centre has been granted Plant
Breeder's Rights for 'Sable' (Certificate No. 0461) and a U.S. plant patent application has been filed. Nurseries interested in securing a propagating license may contact the originating station.

\section{Literature Cited}

Handley, D.T. and J.F. Dill. 2002. Performance of strawberry cultivars grown in a matted-row system in Maine. p. 32-33. In: S.C. Hokanson and A.R. Jamieson (eds.). Strawberry research to 2001. ASHS Press, Alexandria,Va.

Jamieson, A.R., K.A. Sanford, and N.L. Nickerson. 1991. 'Cavendish' strawberry. HortScience 26: 1561-1563.

Moore, J.N. 1970. Fruit size of strawberry cultivars.
Fruit Var. \& Hort. Dig. 24:58-62.

Nickerson, N.L. and A.R. Jamieson 1995. Canadian races of the red stele root rot fungus, Phytophthora fragariae var. fragariae. Adv. Strawberry Res. 14:31-35.

Nickerson, N.L. and R.A. Murray. 1993. Races of the red stele root rot fungus, Phytophthora fragariae, in Nova Scotia. Adv. Strawberry Res. 12:12-16.

Payne, R.W., P.W. Lane, P.G.N. Digby, S.A. Harding, P.K. Leech, G.W. Morgan, A.D. Todd, R. Thompson, G.T. Wilson, S.J. Welham, and R.P. White. 1993. Genstat 5 Release 3 Reference Manual. Clarendon Press. Oxford, U.K.

Scott, D.H., A.D. Draper, and J.L. Maas. 1976. Mass screening of young strawberry seedlings for resistance to Phytophthora fragariae Hickman. HortScience 11:257-258. 